\title{
Dynamics of reactive oxygen species generation in the presence of copper(II)-histidine complex and cysteine
}

\author{
Anna Ząbek-Adamska', Ryszard Drożdż ${ }^{\bowtie}$ and Jerzy W. Naskalski \\ 'Department of Clinical Biochemistry, Diagnostic Division, Jagiellonian University Medical College, Kraków, Poland; ²Department of Medical \\ Diagnostics, Faculty of Pharmacy, Jagiellonian University Medical College, Kraków, Poland
}

\begin{abstract}
Histidine-copper(II) complex $\left(\mathrm{Cu}-\mathrm{His}_{2}\right)$ is a form of bound copper necessary for cellular copper uptake. Due to the high affinity of histidine to copper(II) ions, the binding of copper(II) by histidine is considered a substantial part of plasma antioxidative defense. Also cysteine plays a role in the antioxidative system. However, we show here that in the presence of oxygen the histidine-copper(II) complex plus cysteine produces reactive oxygen species (ROS). Cysteine concentration was assayed using a thiol specific silver-mercury electrode. Hydrogen peroxide was assayed amperometrically using platinum electrode. ROS formation was followed by chemiluminescence of luminol-fluoresceine-enhanced system. Addition of cysteine to $\mathrm{Cu}-\mathrm{His}_{2}$ solution at $\mathrm{pH} 7.4$ in the presence of atmospheric oxygen initiates the synthesis of $\mathrm{H}_{2} \mathrm{O}_{2}$ and generation of ROS, which manifests as a burst of chemiluminescence. The reaction has two stages; in the first stage, cysteine is utilized for the synthesis of an unstable intermediary product which becomes a substrate for ROS formation. Anaerobic conditions inhibit ROS formation. Increased cysteine concentration enhances the lag phase of the oxidative burst without influencing the amount of ROS. The synthesis of ROS (measured by chemiluminescence) is proportional to the concentration of $\mathrm{Cu}-\mathrm{His}$ employed. ROS production can be repetitively initiated by further additions of cysteine to the reaction medium. The study suggests that $\mathrm{Cu}-\mathrm{His}_{2}$ catalyzes cysteine-dependent reduction of oxygen to superoxide employing an intermediary cysteine-copper(I) complex and enabling Fenton reaction with copper and hydrogen peroxide produced as a secondary product. In effect, $\mathrm{Cu}-\mathrm{His}_{2}$ with cysteine may be a source of ROS in biological media.
\end{abstract}

Key words: Cysteine copper complex, cysteine oxidation, hydrogen peroxide formation, histidine copper complex

Received: 01 January, 2013; revised: 28 May, 2013; accepted: 02 December, 2013; availabel on-line: 15 December, 2013

\section{INTRODUCTION}

Biological antioxidative defense systems integrate actions of a variety of low-molecular-mass compounds and enzymes that prevent the formation of major biological oxidants. Among the low-molecular-mass antioxidants, compounds with reducing properties (classified as free radical scavengers) play a crucial role. These include common metabolites such as uric acid, bilirubin, biliverdin, carotenoids, flavonoids, cysteine and glutathione. Another group of compounds participating in the antioxidative defense are proteins sequestering tran- sient metal ions from biological fluids. The best known members of this group include ceruloplasmin (de Silva \& Aust,1993) controlling $\mathrm{Cu}^{2+}$ ions, and ferritin, lactoferrin and transferrin chelating iron (Halliwell, 1994). Low molecular-mass-antioxidants and metal-binding proteins act concurrently in the body, protecting proteins and other compounds from damage by reactive oxygen species generated by cellular metabolism (Tubaro et al., 1998).

Cysteine, whose concentration in the human plasma is about $250 \mu \mathrm{M}$, is a crucial component of the thiol antioxidant system in the extracellular space. It is the main constituent of a specific redox thiol-disulphide buffer which determines properties of numerous proteins and low molecular mass compounds (Biswas et al., 2006). About $3-10 \%$ of the total plasma cysteine is present in a free, reduced form (Ueland, 1995; Giustarini et al., 2011). The thiol group of cysteine participates in various scavenging reactions of free radicals, reduction of lipid peroxides, hydrogen peroxide, and in chelating ions of transient metals. Therefore cysteine, either free or as a component of proteins, is necessary for the prevention of Fenton reaction (Hegde et al., 2010).

Ceruloplasmin binds the majority of $\mathrm{Cu}^{2+}$ maintaining body fluids free of copper ions, and a fraction of copper ions are also bound to free histidine (Sarkar \& Kruck, 1967) and histidine residues of plasma albumin (Deschamps et al., 2003; Moriya et al., 2008). Moreover, some plasma copper ions also associate with cysteine (Sandstead, 1995), threonine, glutamine and asparagine (Casella \& Gullotti, 1983; Brumas et al., 1993; Deschamps et al., 2005). As copper(I) is one of the most active substrates for Fenton reaction, ceruloplasmin and other copper chelators are important elements of the antioxidative defense system. Histidine is a component of the active centers of proteins responsible for the binding of transient metals $\left(\mathrm{Cu}^{2+}, \mathrm{Fe}^{2+/ 3+}\right.$ and others) with high affinity. L-histidine also acts as a hydroxyl radical and singlet oxygen scavenger. Free histidine as well as carnosine and anserine (dipeptides containing histidine) bind copper ions to form high affinity complexes (Wade \& Tucker, 1998; Hodak et al., 2009) which participate in amino acid-dependent transmembrane transport of copper (Goode et al., 1989). Free histidine and histidine incorporated into peptides and proteins is an essential component of the anti-oxidative defense system (Deschamps et al., 2003; Mesu et al., 2006). In the plasma and other body fluids histidine co-

e-mail: ryszard.drozdz@uj.edu.pl

Abbreviations: $\mathrm{Cu}-\mathrm{His}_{2}$, histidine-copper(II) complex; RLU, Relative Light Units 
exists with cysteine and other thiol compounds. However, the properties of the compound histidine-cysteine antioxidative system have not been studied so far. The purpose of the present study was to follow production of reactive oxygen species in a reaction medium combining cysteine and $\mathrm{Cu}-\mathrm{His}_{2}$ in the presence of atmospheric oxygen.

\section{MATERIALS AND METHODS}

The study of cysteine reaction with $\mathrm{Cu}-\mathrm{His}_{2}$ included analysis of varying cysteine and $\mathrm{Cu}-\mathrm{His}_{2}$ concentrations and their ratio on the generation of reactive oxygen species in phosphate buffer $\mathrm{pH}$ 7.4.

All reagents were of analytical grade. Working solutions were prepared using glass-distilled water (with resistivity of $\geq 18 \mathrm{M} \Omega / \mathrm{cm})$. Stock solution of Lcysteine $(20 \mathrm{mM})$ (Sigma) was prepared in $55 \mathrm{mM}$ sodium phosphate buffer, pH 7.4 (POCh Gliwice). Dilutions of the stock solution with the same buffer were prepared directly prior to use. Their final $\mathrm{pH}$ was adjusted to 7.4 with $0.5 \mathrm{M} \mathrm{NaOH}$. The luminol-fluoresceine enhanced detection system was prepared from 5 $\mathrm{mM}$ luminol (Carl Roth) and $5 \mathrm{mM}$ fluoresceine (Fluka). Solution of $\mathrm{Cu}-\mathrm{His}_{2}$ was obtained by mixing buffered solution of $\mathrm{CuCl}_{2}$ (Sigma) and histidine (Sigma) in a molar ratio of 1:4. The two-fold histidine excess assures a lack of unbound copper ions.

The measurement of chemiluminescence was carried out every 1 or 5 s using a Lumat LB 9507 luminometr. The intensity of chemiluminescence was expressed in Relative Light Units (RLU) integrating the curve of chemiluminescence intensity (Drożdż et al., 1998). Each measurement was performed in triplicate and the reported results are mean of the three values.

\section{Measurement of reactive oxygen species generated in $\mathrm{Cu}-\mathrm{His}_{2}$ solution as a function of cysteine concentration}

In a set of experiments samples of 10, 20, 30, 40, $50 \mu \mathrm{l}$ of $10 \mathrm{mM}$ cysteine solution in $55 \mathrm{mM}$ phosphate buffer $\mathrm{pH} 7.4$ were added to a reaction cell containing $500 \mu \mathrm{l}$ of the luminol-fluoresceine enhanced detection system and $20 \mu \mathrm{l}$ of $\mathrm{Cu}-\mathrm{His}_{2}$ (final $\mathrm{Cu}^{2+}$ concentration $0.1 \mathrm{mM}$ ) to give a final cysteine concentration from 0.2 to $1 \mathrm{mM}$. Chemiluminescence generated in this reaction was measured every $5 \mathrm{~s}$. Data visualization was performed using Sigma Plot v.11.0 program.

In further experiments the basic experimental system was constituted with a modified concentrations ratio: 500 $\mu \mathrm{l} \mathrm{Cu-His}{ }_{2}$, final $\mathrm{Cu}^{2+}$ concentration $0.1 \mathrm{mM}, 20 \mu \mathrm{l}$ luminol-fluoresceine enhanced detection system and $50 \mu \mathrm{l}$ of $6 \mathrm{mM}$ cysteine - final conc. $0.5 \mathrm{mM}$. This system was used as a reference (control) in the next experiments.

ROS formation under restricted access of oxygen was measured as described above but the reagents were first deaerated for $3 \mathrm{~min}$ by purging with nitrogen or helium (final $\mathrm{O}_{2}$ concentration was not measured) and the reaction mixture in the measuring chamber was overlaid with liquid paraffin. All additional reagents added were pipetted under the paraffin layer using a Hamilton micro-syringe. The control included the same reagent system with free oxygen access.

To study the effect of cysteine on the $\mathrm{Cu}-\mathrm{His}_{2}$ absorption spectrum $500 \mu \mathrm{l}$ of $\mathrm{Cu}-\mathrm{His}_{2}$ solution in 55 $\mathrm{mM}$ phosphate buffer $\mathrm{pH} 7.4$ (final $\mathrm{Cu}^{2+}$ concentration $0.1 \mathrm{mM}$ ) and $50 \mu \mathrm{l}$ of $6 \mathrm{mM}$ cysteine were added to a $2.5-\mathrm{ml}$ spectrophotometric quartz cuvette. The changes of the $\mathrm{Cu}-\mathrm{His}_{2}$ spectrum were recorded at 300 $\mathrm{nm}$ on a HELIOS $\gamma$ spectrophotometer.

\section{Measurement of cysteine concentration using electrochemical method}

Cysteine concentration was determined using a silver mercury electrode and a reference $\mathrm{Ag} / \mathrm{AgCl}$ electrode in saturated $\mathrm{KCl}$ solution by a procedure described earlier (Drożdż et al., 2007). The analyses were carried out in a work cell $(2.5 \mathrm{ml})$ filled up with 55 $\mathrm{mM}$ phosphate buffer $\mathrm{pH} 7.4$ and a magnetic microstirring bar inside. After several minutes of incubation with working buffer to obtain electrochemical equilibrium between the buffer and the electrode, an electrovoltaic cell was produced by inserting a liquid junction connecting the work cell with the reference-electrode cell. The baseline electric potential (in $\mathrm{mV}$ ) was measured for 3 to $30 \mathrm{~min}$, using an Elmetron CP-401 millivoltmeter. Once the baseline potential was measured, cysteine solution of varying concentrations was added to make a reference cysteine standard curve. The final cysteine concentration was in the range of 0.01 to 20 $\mathrm{mM}$. The electrochemical potential was stable within $\pm 2.0 \mathrm{mV}$.

Time-dependent cysteine concentration changes were also assessed when various cysteine amounts were added to the reaction medium containing $\mathrm{Cu}$ $\mathrm{His}_{2}$ in $55 \mathrm{mM}$ phosphate buffer. These measurements were carried out following addition of $50 \mu \mathrm{l}, 100 \mu \mathrm{l}$, $200 \mu \mathrm{l}, 400 \mu \mathrm{l}, 600 \mu \mathrm{l}, 800 \mu \mathrm{l}$ or $1000 \mu \mathrm{l}$ aliquots of $10 \mathrm{mM}$ cysteine solution into the work-cell containing $1200 \mu \mathrm{l}$ of $\mathrm{Cu}_{-\mathrm{His}_{2}}$ at $0.01 \mathrm{mM} \mathrm{Cu}{ }^{2+}$. The electrode potential was measured every $1 \mathrm{~s}$ until termination of the reaction. Measurement results were automatically re-calculated into cysteine concentration (mM) and expressed as a function of cysteine concentration versus reaction time.

\section{Measurement of hydrogen peroxide formation by amperometry}

$\mathrm{H}_{2} \mathrm{O}_{2}$ concentration was measured by amperometry employing a platinum electrode activated with o-phenylenediamine (O-PD) as described by Liu and Zweiler (2001). The electrode was activated by immersion in an o-phenylenediamine dihydrochloride buffer along with an auxiliary second platinum electrode and a silver/chloride reference electrode. The reference starting potential of the activated platinum electrode versus the silver/chloride electrode was $+900 \mathrm{mV}$. The activated platinum electrode was washed with distilled water and stored in $55 \mathrm{mM}$ phosphate buffer $\mathrm{pH}$ 7.4. The auxiliary platinum electrode was stored in distilled water.

The measurement of $\mathrm{H}_{2} \mathrm{O}_{2}$ was carried out in a workcell containing $9 \mathrm{ml}$ of phosphate buffer $\mathrm{pH} \mathrm{7.4}$. The electrode starting potential versus the reference $\mathrm{Ag} / \mathrm{Cl}$ electrode was $650 \mathrm{mV}$ at room temperature. All measurements were performed in triplicate. The reference relationship between the $\mathrm{H}_{2} \mathrm{O}_{2}$ concentration and current was: $\mathrm{H}_{2} \mathrm{O}_{2}(\mu \mathrm{M})=2.817 \mathrm{nA}-29.527$. In order to measure $\mathrm{H}_{2} \mathrm{O}_{2}$ synthesis in the presence of cysteine, first $500 \mu \mathrm{l}$ of $10 \mathrm{mM}$ cysteine solution in $55 \mathrm{mM}$ phosphate buffer $\mathrm{pH} 7.4$ was added to $9 \mathrm{ml}$ of $55 \mathrm{mM}$ phosphate buffer, incubated for $40 \mathrm{~s}$ (delay), then $400 \mu \mathrm{l}$ of $\mathrm{Cu}-$ $\mathrm{His}_{2}$ solution was added. If not stated otherwise, the final copper concentration employed was $0.1 \mathrm{mM}$. In serial measurements, consecutive aliquots of cysteine were added in 1-min intervals. 


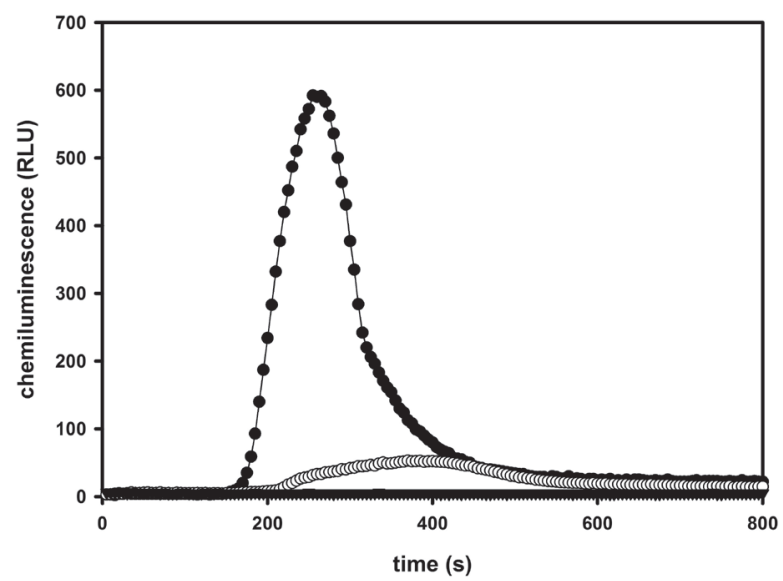

Figure 1. Generation of ROS in a reference system containing cysteine and $\mathrm{Cu}-\mathrm{His}_{2}$.

To $500 \mu \mathrm{l}$ of $\mathrm{Cu}-\mathrm{His}_{2}$ in $55 \mathrm{mM}$ phosphate buffer $\mathrm{pH} 7.4, \mathrm{Cu}^{2+} 0.1$ $\mathrm{mM}$ ) and $20 \mu \mathrm{l}$ of luminol and fluoresceine (a chemiluminescence enhancer), $50 \mu \mathrm{l}$ of $6 \mathrm{mM}$ cysteine hydrochloride ( $)$ was added to obtain final cysteine concentration $0.5 \mathrm{mM}$. Control sample $(\boldsymbol{\Delta})$ contained the same reagents as above without cysteine. Another control $(O)$ contained all the reagents except histidine. Chemiluminescence was measured at 5 -s intervals.

\section{RESULTS}

\section{ROS synthesis in the cysteine - $\mathrm{Cu}-\mathrm{His}_{2}$ reaction system}

Cysteine and $\mathrm{Cu}-\mathrm{His}_{2}$ in phosphate buffer $\mathrm{pH} 7.4$ react and generate ROS, whose appearance is manifested as a chemiluminescence burst owing to the luminolfluorsceine detection system. The reaction is specific for $\mathrm{Cu}-\mathrm{His}_{2}$ and does not occur without histidine as a complexing agent for copper ions. However, the addition of cysteine does not directly initiate the ROS synthesis since the burst of the chemiluminescence appears after some delay, the length of which depends on the final cysteine concentration (Fig. 1). Increasing the cysteine

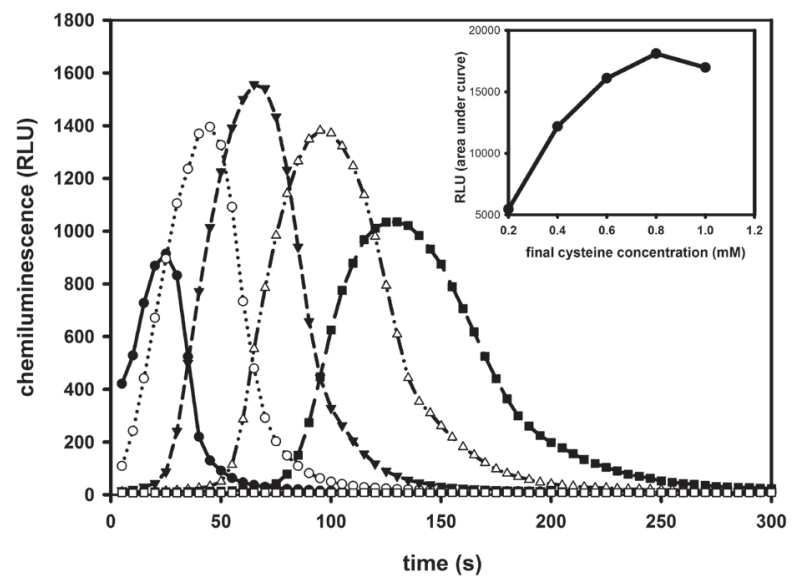

Figure 2. Effect of cysteine concentrations on ROS formation in the presence of $\mathrm{Cu}-\mathrm{His}_{2}$.

To $500 \mu$ of luminol and fluoresceine (a chemiluminescence enhancer) and $20 \mu \mathrm{l}$ of $\mathrm{Cu}-\mathrm{His}_{2}$ (final $\mathrm{Cu}^{2+}$ concentration $0.1 \mathrm{mM}$ ), different volumes of $10 \mathrm{mM}$ cysteine were added $(10-50 \mu \mathrm{l})$ to obtain final cysteine concentrations of $0.2[\mathbf{O}], 0.4[0], 0.5[\boldsymbol{\nabla}], 0.7$ $[\Delta], 9[\square] \mathrm{mM}$. Control sample [ $\square]$ contained the same reagents as above without cysteine. Chemiluminescence was measured at 5-s intervals. The inset shows total of RLU intensity that corresponds to ROS generation as a function of cysteine concentration.

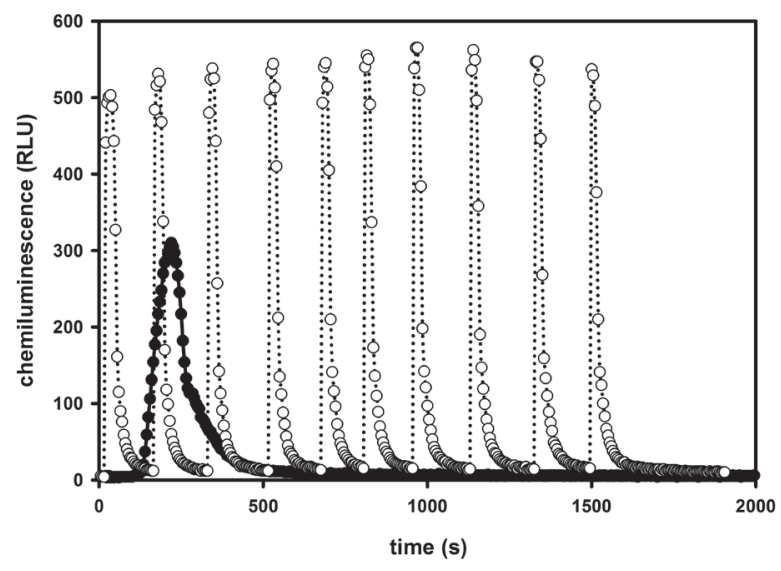

Figure 3. Effect of repeated additions of cysteine to the reaction medium with $\mathrm{Cu}-\mathrm{His}_{2}$.

Reaction conditions were as in Fig. 1, but cysteine was supplied in ten 5 - $\mu$ l aliquots of a $6 \mathrm{mM}$ stock (total final concentration 0.5 $\mathrm{mM})$, each added to the reaction mixture after termination of chemiluminescence $(\mathrm{O})$. Chemiluminescence was measured at 5 -s intervals. The reference system composed of cysteine - $\mathrm{Cu}-\mathrm{His}_{2}$ described in Fig. 1. was the control sample (-).

concentration from 200 to $1000 \mu \mathrm{M}$ prolonged the delay of the light burst from 10 to $120 \mathrm{~s}$ (Fig. 2). The duration of the chemiluminescence increased proportionally to the cysteine concentration. At the highest cysteine concentration employed $(1 \mathrm{mM})$ the light emission began at $120 \mathrm{~s}$, achieved its maximum at $165 \mathrm{~s}$, and terminated at about $200 \mathrm{~s}$. The cysteine concentration also determined the intensity of the light emitted and the amount of ROS formed (calculated as the area under the RLU curve). However, with increasing cysteine concentration the amount of ROS formed per micromole of cysteine actually decreased (Table 1).

The amount of ROS generated depends not only on total amount of cysteine but also on dosing mode of the constant amount of thiol. When $50 \mu \mathrm{l}$ of $6 \mathrm{mM}$ cysteine was divided into two, five or ten portions and consecutively added to the $\mathrm{Cu}-\mathrm{His}_{2}$ solution after the end of the previous chemiluminescence burst, the amount of ROS formed (estimated as a sum of all oxidative bursts)

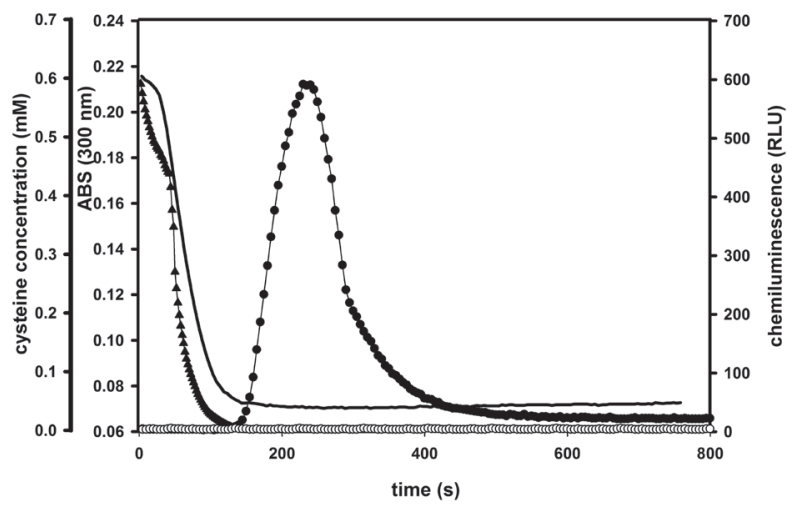

Figure 4. Generation of ROS as a result of cysteine depletion in the reaction medium.

Generation of reactive oxygen species [O] occurred when cysteine was depleted from the reaction mixture $[\boldsymbol{\Lambda}]$. Cysteine concentration was followed using a thiol-specific silver-mercury electrode. ROS generation was followed by intensity of chemiluminescence. Changes of $\mathrm{Cu}-\mathrm{His}_{2}$ absorption under the influence of cysteine were determined spectrophotometrically at $300 \mathrm{~nm}[-]$. Experimental conditions were as described in Fig. 1. 
Table 1. ROS generation at different concentrations of cysteine.

Amount of ROS generated was estimated as amount of chemiluminescence (area under curve) at constant $\mathrm{Cu}-\mathrm{His}_{2}$ concentration (final $\mathrm{Cu}^{2+} 0.1 \mathrm{mM}$ ).

\begin{tabular}{llc}
\hline $\begin{array}{l}\text { Cysteine concentration } \\
(\mathrm{mM})\end{array}$ & $\begin{array}{l}\text { Area under curve } \\
(\mathrm{RLU}) \pm \text { S.D. }\end{array}$ & $\mathrm{RLU} / \mathrm{mM}$ of cysteine \pm S.D. \\
\hline 0.2 & $5453 \pm 299$ & $27266 \pm 1497$ \\
\hline 0.4 & $12186 \pm 1051$ & $30465 \pm 2628$ \\
\hline 0.5 & $16110 \pm 641$ & $26850 \pm 1069$ \\
\hline 0.7 & $18113 \pm 324$ & $22641 \pm 405$ \\
\hline 0.9 & $16979 \pm 130$ & $16979 \pm 130$ \\
\hline
\end{tabular}

increased progressively with the number of aliquots (Fig. 3, Table 2). The experiment described above suggests that $\mathrm{Cu}-\mathrm{His}_{2}$ acts as a catalyst mediating oxidation of cysteine following each new addition of the substrate. Measured by chemiluminescence generation of ROS takes place at the end of each cycle after depletion of cysteine and is performed by active, reduced form of the copper complex and cumulated hydrogen peroxide. The proposed catalytic function of $\mathrm{Cu}-\mathrm{His}_{2}$ in cysteinedependent ROS formation is in agreement with the finding that the intensity of chemiluminescence was directly proportional to the concentration of $\mathrm{Cu}-\mathrm{His}_{2}$ (Table 3), and that the delay of ROS synthesis was inversely proportional to the $\mathrm{Cu}^{2+}$ concentration.

The ROS formation always began after some delay from the time of cysteine addition. Potentiometric analysis of cysteine concentration changes in the reaction medium containing $\mathrm{Cu}-\mathrm{His}_{2}$ indicated that the cysteine concentration decreases during the first reaction stage and falls to zero before the ROS synthesis begins (Fig. 4). It is known that copper ions catalyze oxidation of cysteine (Kachur et al., 1999; Munday et al., 2004), while the highly nucleophilic thiolate anion is a potential substrate for a new complex of copper(I) with cysteine. This complex probably reduced oxygen, which resulted in the formation of $\mathrm{O}_{2}^{-}$which accumulated in the reaction medium. The proposed mechanism is in agreement with our

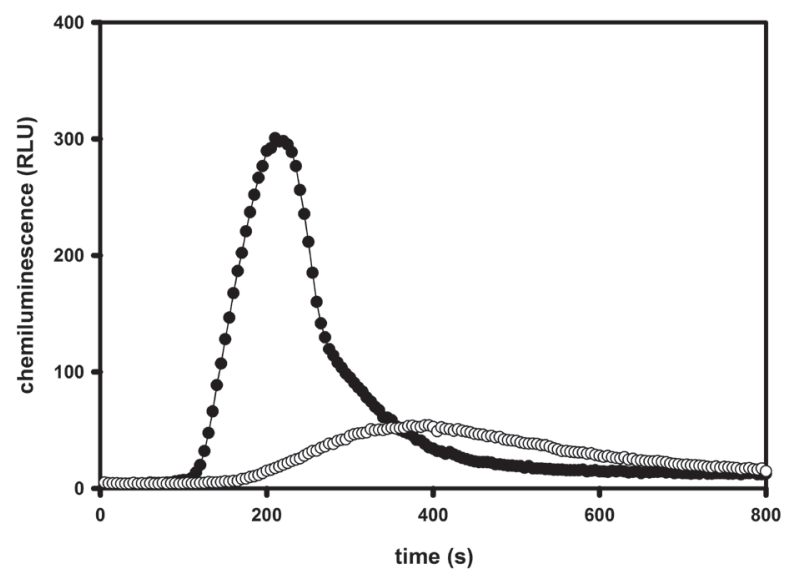

Figure 5. Influence of molecular oxygen on formation of ROS in the $\mathrm{Cu}-\mathrm{His}_{2}$-cysteine system.

ROS formation by cysteine and $\mathrm{Cu}-\mathrm{His}_{2}$ depends on oxygen access (unlimited [O] or restricted [O]) to the reaction medium. Experimental conditions were as described in Fig. 1, but oxygen was removed from the reagents $\left(\mathrm{Cu}-\mathrm{His}_{2}\right.$ and luminol and fluoresceine) by deaeration with helium and in sample 2 the reaction medium was separated from the atmosphere by a 3-mm layer of liquid paraffin. Cysteine was injected under the paraffin layer (final concentration $0.5 \mathrm{mM}$ ). Chemiluminescence was measured at 5-s intervals. finding that duration of the first "silent" stage of the reaction depended positively on the cysteine concentration in the solution. As long as copper was bound to cysteine, it prevented oxygen reduction, but when the cysteine was oxidized, copper(I) was released to the medium and a rapid synthesis of ROS occurred through Fenton reaction. Copper(II) produced in this reaction was bound again into the complex with histidine.

\section{Involvement of oxygen in ROS synthesis}

Deaeration of the reaction solutions with nitrogen or helium prior to the addition of cysteine and limitation of atmospheric oxygen access by a liquid paraffin layer caused a remarkable decrease in ROS formation (Fig. 5). This observation strongly indicates that an intermediary cysteine copper complex specifically reduced oxygen. Formation of $\mathrm{H}_{2} \mathrm{O}_{2}$ in the reaction medium suggested that oxygen was reduced to the $\mathrm{O}_{2}{ }^{-}$radical, which eventually dismutated to $\mathrm{H}_{2} \mathrm{O}_{2}$. Our experiments showed that each addition of cysteine initiated $\mathrm{H}_{2} \mathrm{O}_{2}$ formation. We propose that oxygen is the other substrate necessary for cysteine-mediated ROS formation in the presence of $\mathrm{Cu}-\mathrm{His}_{2}$.

\section{$\mathrm{H}_{2} \mathrm{O}_{2}$ synthesis in the presence of cysteine and $\mathrm{Cu}-\mathrm{His}_{2}$}

In our oxidation model a decrease in cysteine concentration is accompanied by production of $\mathrm{H}_{2} \mathrm{O}_{2}$ as measured by an amperometric system (Fig. 4, Fig. 6). Electrometric follow up of synthesized $\mathrm{H}_{2} \mathrm{O}_{2}$ showed that the synthesis terminated at a certain level which depended on the concentration of cysteine added to the medium. Once the synthesis of $\mathrm{H}_{2} \mathrm{O}_{2}$ terminated (about $5 \mathrm{~min}$ after addition of cysteine), addition of a new portion of cysteine resulted in new synthesis of $\mathrm{H}_{2} \mathrm{O}_{2}$ that continued for another $2 \mathrm{~min}$. In effect, the total $\mathrm{H}_{2} \mathrm{O}_{2}$ concentration in the sample increased (not shown). However, addition of cysteine before the termination of the initial synthesis of $\mathrm{H}_{2} \mathrm{O}_{2}$ halted its synthesis for a time necessary for the free cysteine to disappear from the reaction medium. Then, the synthesis of $\mathrm{H}_{2} \mathrm{O}_{2}$ started again. Each

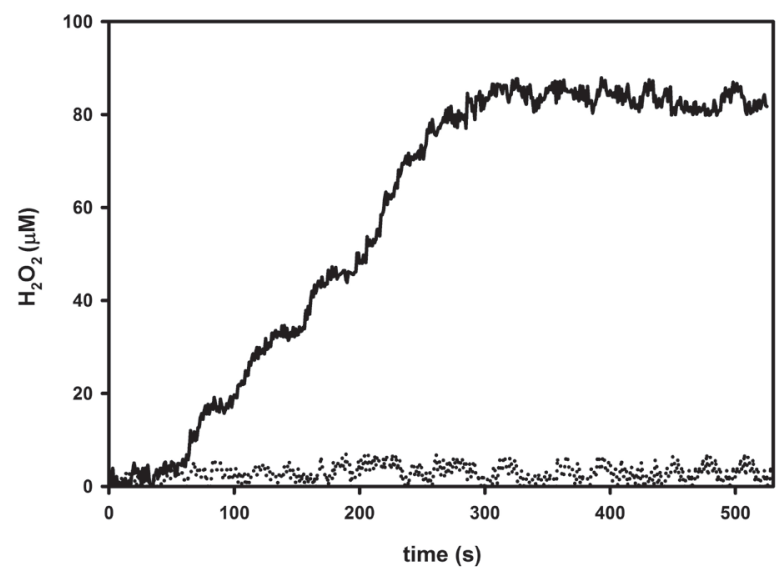

Figure 6. Generation of $\mathrm{H}_{2} \mathrm{O}_{2}$ in reaction of cysteine with $\mathrm{Cu}-\mathrm{His}_{2}$ at unlimited access of oxygen.

Cysteine was added to $9 \mathrm{ml}$ of $55 \mathrm{mM}$ phosphate buffer $\mathrm{pH} 7.4$ to obtain final concentration equal to $0.5 \mathrm{mM}$. After $40 \mathrm{~s} \mathrm{Cu}-\mathrm{His}_{2}$ was added to obtain $\mathrm{Cu}(\mathrm{II})$ concentration of $0.1 \mathrm{mM}$ [-] . The control did not contain $\mathrm{Cu}-\mathrm{His}_{2}[\ldots] . \mathrm{H}_{2} \mathrm{O}_{2}$ concentration was measured by amperometric method at 1 -s intervals. 
Table 2. Generation of ROS as a result of dosing mode of $50 \mu \mathrm{l}$ of $6 \mathrm{mM}$ cysteine (two $25-\mu \mathrm{l}$, five $10-\mu \mathrm{l}$ and ten $5-\mu \mathrm{l}$ portions) to the $\mathrm{Cu}-\mathrm{His}_{2}$ solution.

\begin{tabular}{|c|c|c|c|c|}
\hline $\begin{array}{l}\text { Cysteine portions } \\
\text { added to } \mathrm{Cu}-\mathrm{His}_{2} \\
\text { solution }\end{array}$ & $\begin{array}{l}\text { Height of chemi- } \\
\text { lum-inescence peak } \\
\text { (RLU) }\end{array}$ & $\begin{array}{l}\text { Area under curve for } \\
\text { control samples } \pm \text { S.D. }\end{array}$ & $\begin{array}{l}\text { Area under curve for rese- } \\
\text { arch samples }(R L U) \pm S . D \text {. }\end{array}$ & $\begin{array}{l}\text { Increase of chemiluminescence } \\
\text { (compared with control sam- } \\
\text { ple) } \pm \text { S.D. }\end{array}$ \\
\hline $2 \times 25 \mu l$ & 779 & $9427 \pm 127$ & $9591 \pm 818$ & $164 \pm 13$ \\
\hline $5 \times 10 \mu l$ & 650 & $10710 \pm 582$ & $18449 \pm 734$ & $7739 \pm 746$ \\
\hline $10 \times 5 \mu l$ & 635 & $7583 \pm 912$ & $33664 \pm 1440$ & $26081 \pm 6779$ \\
\hline
\end{tabular}

Table 3. ROS generation at different concentrations of $\mathrm{Cu}-\mathrm{His}_{2}$ and constant cysteine concentration (final $0.5 \mathrm{mM}$ ).

Cu-His ${ }_{2}$ concentration (mM) Area under curve (RLU) \pm S.D. RLU/mM of Cu-His ${ }_{2} \pm$ S.D.

\begin{tabular}{lcc}
\hline 0.05 & $2802 \pm 152$ & $56040 \pm 3040$ \\
\hline 0.1 & $5809 \pm 199$ & $58090 \pm 1990$ \\
\hline 0.2 & $10430 \pm 197$ & $52150 \pm 985$ \\
\hline
\end{tabular}

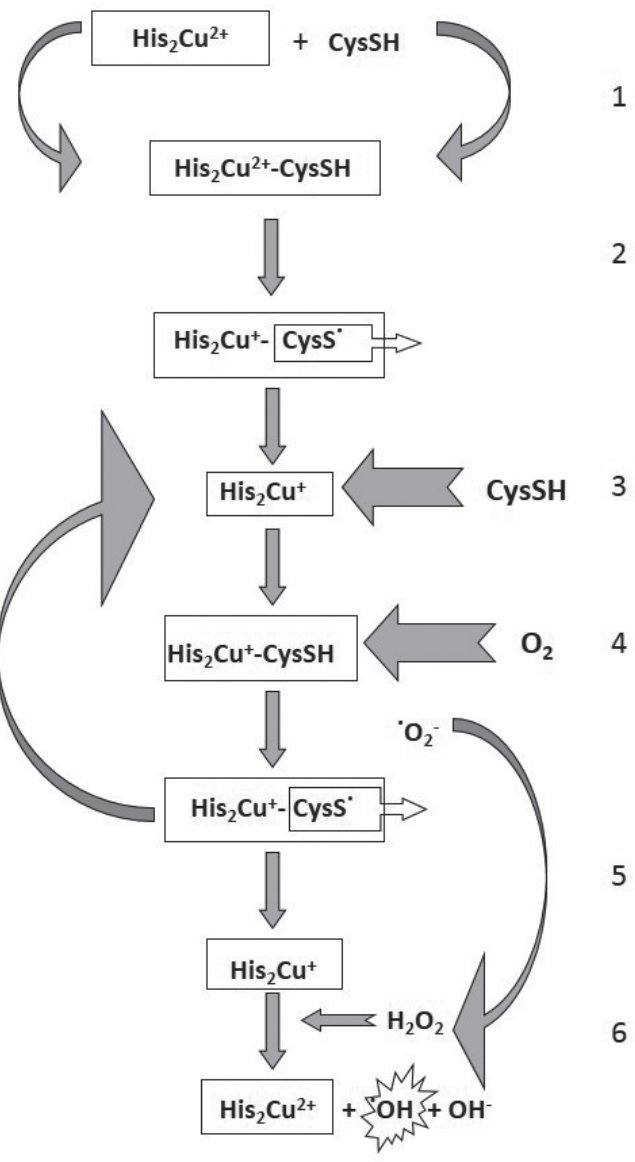

Figure 7. Proposed mechanism of cysteine-dependent ROS formation in the presence of the histidine-copper complex.

(1) Incorporation of cysteine to the histidine-copper(II) complex. (2) Internal oxidation of cysteine by copper(II). Thiyl radical of cysteine is released from the complex. It undergoes a further conversions, not shown. (3) Cysteine is incorporated into the histidine-copper(I) complex. (4) One electron oxidation of complexed cysteine by molecular oxygen. Thiyl and superoxide radicals are released. (5) Superoxide anion forms hydrogen peroxide as a result of spontaneous dismutation. Formation of molecular oxygen is not shown. (6) When cysteine is removed from the solution, hydrogen peroxide in the presence of copper $(\mathrm{I})$ ions is converted to reactive hydroxyl radical in the Fenton reaction. Simultaneously, the histidine-copper(II) complex is regenerated and may react in another cycle with a new molecule of cysteine. new addition of small amounts of cysteine caused accumulation of $\mathrm{H}_{2} \mathrm{O}_{2}$ in the reaction medium ( $\mathrm{Ta}-$ ble 4). However, in the presence of cysteine also some reduction of $\mathrm{H}_{2} \mathrm{O}_{2}$ occurred, which was observed as a progressing decrease of the $\mathrm{H}_{2} \mathrm{O}_{2}$ electrode signal.

\section{DISCUSSION}

L-histidine binds copper, cobalt, zinc, cadmium and other bivalent transitory metal ions into stable tridentate complexes (Hofstetter et al., 2011). Blood plasma practically does not contain unbound copper since it is associated with histidine residues in the binding center of ceruloplasmin or those of albumin. Cu-His 2 that constitutes about $5 \%$ of the total blood plasma copper content coordinates some of the exchangeable pool of copper in the blood (Deschamps et al., 2005). However, as shown in this study, even histidine- bound copper(II) in a high affinity complex can participate in generation of free radicals in the presence of cysteine. This process includes cysteine-dependent reduction of oxygen leading to the synthesis of superoxide and hydrogen peroxide. At a physiological $\mathrm{pH}$ protonated thiols express low reactivity toward oxygen and hydrogen peroxide, but introduction of $\mathrm{Cu}-\mathrm{His}_{2}$ leads to the activation of the cysteine reducing ability, similarly as it was documented for $\mathrm{Cu}^{2+/ 1+}$, $\mathrm{Fe}^{3+/ 2+}$ ions in PBS solution and other transient metals (Lynch \& Frei, 1997; Ullah et al., 2011). One of the possible mechanisms of the cysteine- dependent ROS formation in the presence of $\mathrm{Cu}-\mathrm{His}_{2}$ may include reduction of copper(II) to copper(I) (Fig. 7). However, prior to this process, formation of an unstable intermediary cysteine-copper compound, either free or bound to histidine, may represent a primary product of reaction of cysteine with $\mathrm{Cu}-\mathrm{His}_{2}$.

The amount of generated intermediate necessary for the reduction of oxygen molecule to $\mathrm{O}_{2}^{-}$depends on the amount of cysteine added. The superoxide radical produced in the presence of cysteine is immediately dismutated and production of $\mathrm{H}_{2} \mathrm{O}_{2}$ may be demonstrated

Table 4. $\mathrm{H}_{2} \mathrm{O}_{2}$ formation in reaction of $\mathrm{Cu}-\mathrm{His}_{2}$ with cysteine following sequential addition of cysteine.

\begin{tabular}{lc}
\hline $\begin{array}{l}\text { Portion of cysteine } \\
\text { added }\end{array}$ & $\begin{array}{l}\text { Amount of generated } \mathrm{H}_{2} \mathrm{O}_{2}(\mu \mathrm{mol}) \pm \mathrm{S} . \mathrm{D} . \\
\text { by addition of } 200 \mu \mathrm{m} 6 \mathrm{mM} \text { cysteine to } \\
\mathrm{Cu}-\mathrm{His}_{2}\end{array}$ \\
\hline 1 & $21.3 \pm 0.9$ \\
\hline 2 & $35.0 \pm 1.2$ \\
\hline 3 & $46.5 \pm 1.6$ \\
\hline 4 & $57.0 \pm 0.7$ \\
\hline 5 & $64.8 \pm 1.0$ \\
\hline
\end{tabular}


by amperometry. When cysteine is completely depleted from the reaction medium the $\mathrm{H}_{2} \mathrm{O}_{2}$ formed can undergo Fenton reaction with complexed copper (I) to give the hydroxyl radical, which in our luminol-fluoresceine detection system generated a burst of chemiluminescence. After oxidation of copper (I) to copper(II) reconstitution of $\mathrm{Cu}-\mathrm{His}_{2}$ occurs and the reaction cycle may start again if a new portion of cysteine is supplied. Our results are in accord with the suggestion by Theopphanides and Anastosopulou (2002) that copper ions attached to albumin or to free amino acids in the presence of biological reductants can interact with $\mathrm{O}_{2}^{-}$or $\mathrm{H}_{2} \mathrm{O}_{2}$ leading to the formation of hydroxyl radicals.

Oxidation of cysteine in the presence of histidinebound copper may occur through a mechanism known from previous studies on oxidation of amino acids in the presence of transition metals forming complexes with a thiol (Kachur et al., 1999). Reduced cysteine (RSH) binds metal ions. The cysteine thiol group may competitively bind to histidine-copper complex to form a thiolate complex. The nucleophilic properties of the cysteine -SH residue increase when it is transformed to a thiolate anion (RS-) (Ueland, 1995) and a thiolate-copper complex may oxidize an oxygen molecule and yield $\mathrm{Cu}^{1+}$. A similar mechanism was proposed by Pecci et al. (1997) who demonstrated that $\mathrm{Cu}^{2+}$ ions form with cysteine a cuprous bis-cysteine complex which reduces oxygen, cytochrome and nitroblue tetrazolium. This process can also lead to reduction of copper(II) to $\mathrm{Cu}(\mathrm{I})$. The copper(I) bis-cysteine complex is relatively stable under anaerobic conditions, but introduction of oxygen leads to complex formation of $\mathrm{Cu}(\mathrm{I})$-oxygen adducts which facilitate two-electron transfer to give cysteine and $\mathrm{H}_{2} \mathrm{O}_{2}$. The copper remains reduced until all cysteine is oxidized. Khossravi and Borchard (1998) studied metal-catalyzed oxidation of cysteine and histidine in the presence of $\mathrm{H}_{2} \mathrm{O}_{2}$ and proposed that combination of copper(II) and a strong reducer leads to the generation of $\mathrm{Cu}(\mathrm{I})$ which becomes a substrate for Fenton type reaction:

$\mathrm{Cu}^{2+}+\mathrm{RH}^{-}<--->\mathrm{Cu}^{1+}+\mathrm{R}^{-}+\mathrm{H}^{+}$

$\mathrm{Cu}^{2+}+\mathrm{A}^{-}<---->\mathrm{Cu}^{1+}+\mathrm{A}$

The species formed in the reactions presented above can then react with $\mathrm{O}_{2}$ to form ROS, including $\mathrm{O}_{2}^{-}$, $\cdot \mathrm{OH}$ and $\mathrm{H}_{2} \mathrm{O}_{2}$.

Another factor promoting reduction of copper(II) to copper(I) in the presence of cysteine may be the influence of histidine on the properties of the complexed copper. Histidine decreases the redox potential of the $\mathrm{Cu}(\mathrm{II}) / \mathrm{Cu}(\mathrm{I})$ couple, thus facilitating reduction of copper(II) and its entering into Fenton reaction (Gaubert et al., 2000). It means that in the presence of Cu-His ${ }_{2} \mathrm{Ox}^{-}$ ygen may undergo one-electron reduction to form $\mathrm{O}_{2}$. Therefore $\mathrm{Cu}-\mathrm{His}_{2}$ seems to have contrasting properties, acting both as a chelator removing $\mathrm{Cu}^{2+}$ from biological fluids, and as a copper(I) source that facilitates Fenton reaction and hydroxyl radical formation. Such an effect is observed in $\mathrm{Zn}$, Cu superoxide dismutase (EC 1.15.1.1) which contains copper(II) bound to four imidazole residues of histidine. In ceruloplasmin, copper(II) is bound to histidine 426. However, reduction of the complexed copper may occur and in effect ceruloplasmin also has oxidative properties, which are utilized in the oxidation of $\mathrm{Fe}(\mathrm{II})$ to $\mathrm{Fe}(\mathrm{III})$ (Shukla et al., 2006). The influence of histidine on the susceptibility of the complexed copper to reduction increases when the histidine is located at the N-terminal position of a polypeptide chain (Ueda et al., 2000). Finally, free $\mathrm{Cu}_{-\mathrm{His}_{2}}$ at physiological concentrations (about $25 \mu \mathrm{M}$ ) acts as a superoxide scaven- ger, while at higher concentrations $(250 \mu \mathrm{M})$ it catalyzes dismutation of $\mathrm{O}_{2}^{-}$to $\mathrm{H}_{2} \mathrm{O}_{2}$ and finally hydroxyl radical formation (Ueda et al., 1994).

Experiments described above indicate that cysteine is not directly involved in the synthesis of $\mathrm{H}_{2} \mathrm{O}_{2}$. On the contrary, cysteine inhibits $\mathrm{H}_{2} \mathrm{O}_{2}$ synthesis, probably by decomposing the superoxide produced by oxygen reduction. This process, however, occurs in parallel to the reaction of cysteine with $\mathrm{Cu}-\mathrm{His}_{2}$ yielding an intermediary product causing one-electron reduction of molecular oxygen. Such properties are shown by certain cysteine-copper(I) complexes, conceivably formed as the reaction by-products. Once cysteine is depleted from the reaction medium, $\mathrm{O}_{2}^{-}$produced in the reaction of the intermediary product with oxygen can accumulate and dismutate to $\mathrm{H}_{2} \mathrm{O}_{2}$, which is detected in the reaction medium.

Association of copper ions with albumin, carbohydrates or enzymes can lead to in-site ROS formation in vivo. Site-specific metal-catalyzed oxidation that affects some specific amino acid residues located at the metal binging sites has been observed for histidine, arginine, methionine, lysine, proline and cysteine (Trigwell et al., 2001). Cysteine, which forms complexes with $\mathrm{Cu}(\mathrm{II})$ or $\mathrm{Fe}(\mathrm{III})$, is the most susceptible to metal-catalyzed oxidation. In effect, generation of ROS occurs within complexes of metal and cysteine, leading to oxidation of the specific local amino acid residues (Stadman, 1990). Results obtained in our studies contribute to better understanding of the mechanisms of the copper-mediated damage produced under aerobic conditions.

\section{Acknowledgements}

This study was supported by Jagiellonian University Medical College institutional funds.

Conflict of interests: none

\section{REFERENCES}

Biswas S, Chida AS, Rahman I (2006) Redox modifications of proteinthiols: emerging roles in cell signaling. Biochem Pharmacol 71: 551564.

Brumas V, Alliey N, Berthon GA (1993) New investigation of copper(II)-serine, copper(II)-histidine-serine, copper(II)-asparagine, and copper(II)-histidine-asparagine equilibria under physiological conditions, and implications for simulation models relative to blood plasma. J Inorg Biochem 52: 287-296.

Casella L, Gullotti M (1983) Coordination modes of histidine 4. Coordination structures in the copper(II)-L-histidine(1:2) system. J Inorg Biochem 18: 19-31.

De Silva DM, Aust SD (1993) Ferritin and ceruloplasmin in oxidative damage: review and recent findings. Can J Physiol Pharmacol 71: 715-720.

Deschamps P, Kulkarni PP, Gautam-Basak M, Sarkar B (2005) The saga of copper(II)-L-histidine. Coord Chem Rev 249: 895-909.

Deschamps P, Kulkarni PP, Sarkar B (2003) The crystal structure of a novel copper(II) complex with asymmetric ligand derived from 1histidine. Inorg Chem 42: 7366-7368.

Drożdż R, Parmentier C, Hachad H, Leroy P, Siest G, Wellman M (1998) Gamma-glutamyltransferase dependent generation of reactive oxygen species from a glutathione/transferrin system. Free Radic Biol Med 25: 786-792.

Drożdż R, Ząbek-Adamska A, Naskalski JW (2007) Potentiometric determination of cysteine with thiol sensitive silver-mercury electrode. Acta Biochim Polon 54: 202-212.

Gaubert S, Bouchaut M, Brumas V, Berthon G (2000) Copper-ligand interactions and the physiological free radical processes. Part 3. Influence of histidine, salicylic acid and anthranilic acid on copperdriven Fenton chemistry in vitro. Free Radic Res 32: 451-461.

Giustarini D, Dalle-Donne I, Milzani A, Rossi R (2011) Low molecular mass thiols, disulfides and protein mixed disulfides in rat tissues: influence of sample manipulation, oxidative stress and ageing. Mech Ageing Dev 132: 141-148. 
Goode CA, Dinh CT, Linder MC (1989) Mechanism of copper transport and delivery in mammals: review and recent findings. $A d v$ Exp Med Biol 258: 131-144.

Halliwell B (1994) Free radicals and antioxidants: a personal view. Review Nutr Rev 52: 253-265.

Hegde ML, Hegde PM, Holthauzen LMF, Hazra TK, Rao, KSJ, Mitra S (2010) Specific inhibition of NEIL-initiated repair of oxidized base damage in human genome by copper and iron. Potential etiological linkage to neurodegenerative diseases. I Biol Chem 285: 28812-28825.

Hodak M, Chisnell R, Lu W, Bernholc J (2009) Functional implications of multistage copper binding to the prion protein. Proc Natl Acad Sci USA 106: 11576-11581.

Hofstetter TE, Howder CR, Berden G, Oomens J, Armentrout PB (2011) Structural elucidation of biological and toxicological complexes: Investigation of monomeric and dimeric complexes of histidine with multiply charged transition metal ( $\mathrm{Zn}$ and $\mathrm{Cd}$ ) cations using IR action spectroscopy. J Phys Chem B 115: 12648-12661.

Kachur AV, Koch CJ, Biaglow JE (1999) Mechanism of copper-catalyzed autoxidation of cysteine. Free Radic Res 31: 23-34.

Khossravi M, Borchard RT (1998) Chemical pathways of peptide degradation. IX Metal catalyzed oxidation of histidine in model peptides. Pharm Res 15: 1096-1102.

Liu X, Zweier JL (2001) A real-time electrochemical technique for measurement of cellular hydrogen peroxide generation and consumption: evaluation in human polymorphonuclear leukocytes. Free Radic Biol Med 31: 894-901.

Lynch SM, Frei B (1997) Physiological thiol compounds exert pro- and anti-oxidant effects, respectively, on iron- and copper-dependent oxidation of human low-density lipoprotein. Biochim Biophys Acta 1345: 215-221.

Mesu JG, Visser T, Soulimani F, van Faassen EE, de Peinder P, Beale AM, Weckhuysen BM (2006) New Insights into the coordination chemistry and molecular structure of copper(II) histidine complexes in aqueous solutions. Inorg Chem 45:1960-1971.

Moriya M, Ho YH, Grana A, Nguyen L, Alvarez A, Jamil, R. Ackland, M.L. Michalczyk A (2008) Copper is taken up efficiently from albumin and alpha2-macroglobulin by cultured human cells by more than one mechanism. Am J Physiol Cell Physiol 295: C708-C721.

Munday R, Munday CM, Winterbourn CC (2004) Inhibition of coppercatalyzed cysteine oxidation by nanomolar concentrations of iron salts. Free Radic Biol Med 36: 757-766.
Pecci L, Montefoschi G, Cavallini D (1997) Some new details of the copper-hydrogen peroxide interaction. Biochem Biophys Res Commun 235: $264-267$.

Sandstead HH R (1995) Requirements and toxicity of essential trace elements, illustrated by zinc and copper. Review. Am J Clin Nutr $\mathbf{6 1}$ (3 Suppl): 621S-624S.

Sarkar B, Kruck TP (1967) Separation of Cu(II)-amino acid complexes and evidence for the existence of histidine- $\mathrm{Cu}(\mathrm{II})$-glutamine and histidine-Cu(II)-serine complexes at physiological pH. Can J Biochem 45: 2046-2049.

Shukla N, Maher J, Masters J, Angelini GD, Jeremy JY (2006) Does oxidative stress change ceruloplasmin from a protective to a vasculopathic factor? Atherosclerosis 187: 238-250.

Stadman ER (1990) Metal catalyzed oxidation of proteins: Biochemical mechanism and biologic consequences. Free Radic Biol Med 9: 315-325.

Theopphanides T, Anastosopulou J (2002) Copper and carcinogenesis. Crit Rev in Oncol and Hematol 42: 57-64.

Trigwell SM, Radford PM, Page SR, Loweth AC, James RF, Morgan NG. Todd I (2001) Islet glutamic acid decarboxylase modified by reactive oxygen species is recognized by antibodies from patients with type 1 diabetes mellitus. Clin Exp Immunol 126: 242-249.

Tubaro F, Ghiselli A, Rapuzzi P, Maiorino M, Ursini F (1998) Analysis of plasma antioxidant capacity by competition kinetics. Free Radic Biol Med 241: 228-1234.

Ueda J, Sudo A, Mori A, Ozawa T (1994) Generation of hydroxyl radicals during dismutation of superoxide by SOD model compounds. Arch Biochem Biophys 315: 1895-1899.

Ueda JI, Hanaki A, Hatano K, Nakajima T (2000) Autoxidation of ascorbic acid catalyzed by the copper(II) bound to L-histidine oligopeptides, (His) i Gly and acetyl-(His) i Gly (i=9, 19, 29). Relationship between catalytic activity and coordination mode. Chem Pharm Bull (Tokyo) 48: 908-913.

Ueland PM (1995) Homocysteine species as components of plasma redox thiol status. Clin Chem 41: 340-342.

Ullah MF, Ahmad A, Zubair H, Khan HY, Wang Z, Sarkar FH, Hadi S M (2011) Soy isoflavone genistein induces cell death in breast cancer cells through mobilization of endogenous copper ions and generation of reactive oxygen species. Mol Nutr Food Res 55: $553-$ 559.

Wade AM, Tucker HN (1998) Antioxidant characteristics of L-histidine. J Nutr Biochem 9: 308-315. 